( 8 )

\title{
垂直跳および着地動作におけるパワー発揮の 大きさと下肢関節の貢献度
}

(筑波大学) 阿 江 通 良, 大 木昭一郎, 高 松 潤二

\section{1. 緒言}

体育・スポーツで用いられる運動では, 大きな力 やパワーの発揮が要求されることが多い.このよう な運動では, 力やパワ一を発揮するための身体資源 としての体力に優れているのみではなく，これらの 身体資源を力学的エネルギとして外部へ発揮するた めの身体の有効な使い方が特に重要である。しか し，身体の使い方や役割の程度，すなわち運動への 身体各部の貢献度は, 各種の要因, 例えば運動者の 身体特性 ${ }^{1)}$, 運動課題 ${ }^{2-4)}$, 疾走スピード5)などによ り大きく異なることが知られている。一方，運動を 決定あるいは制御する基準や原則，あるいは運動を 最適化する場合の目的関数についても, トルク変化 最小 ${ }^{6)}$, 総代謝エネルギにもとづく移動仕事率7), 筋パワーの積分値 ${ }^{8}$ などの様久な提案がなされてい る。また, 垂直跳動作の最適化では最大跳躍高, 動 作時間9,10)などを，重量挙げではバーベルの軌跡 ${ }^{11)}$ などを拘束条件としている。これらのことは，運動 の種類や課題, 要求される力やパワーの大きさなど によって運動の決定基準や目的関数も異なることを 示唆していると考えられる。

したがって, 運動の条件が変化したとき, 身体各 部の貢献度がどのように変化するかをとらえ，これ らに影響をおよぼす要因を知ることは，運動技術や その指導法を究明寸るのみではなく, 運動を決定し たり，制御している原則や基準を明らかにするため の基礎的知見を提供すると考えられる。

本研究の目的は, 大きなパワーの要求される運動
の中から，垂直跳の踏切動作扝よび跳び降りからの 着地動作（以下, 着地動作）をとりあげ, 重直跳で は跳躍高を, 着地動作では跳び降り高(以下, 台高) を変化させたときの下肢関節モーメントによるパワ 一, 力学的仕事, 下肢関節の貢献度の変化を明らか にするとともに，よい動きを考える場合の観点（仮 説）を提示することである。

\section{2. 方法}

\section{1 被 験 者}

被験者には, 短距離, 跳躍, 十種競技を専門とす る大学男子陸上競技選手を, 垂直跳では 15 名(体重 $64.3 \pm 4.9 \mathrm{~kg}$ ), 着地動作では11 名（体重 $64.3 \pm$ $5.6 \mathrm{~kg})$ 用いた。

\section{2 実験試 技}

実験試技として垂直跳および跳び降りからの着地 動作を以下のようにして行わせた。これらの試技 は，すべて裸足で行わせ，試技間には少なくとも 3 分間以上の休息をとらせ, 疲労の影響がないように した。

\section{2 .1 垂 直 跳}

両腕の振込動作を用いない脚のみの反動垂直跳 （腕で腰のベルトを握らせた）を最大努力 $(100 \%)$, および最大努力を基準とした主観的努力度 90 ，80， 60，45，30\%でランダムにそれぞれ 2-3 回行わせ た. 実験の前には，跳躍高をモニターしながら，い くつかの努力度で数回の練習を行わせた。実験セッ 
ションでは結果（跳躍高）や試技の成功不成功につ いての情報を与えたが，踏切動作については何も指 示しなかった。

\subsection{2 着地動 作}

高さ $0.25,0.4,0.6,0.8,1.0 \mathrm{~m}$ の 5 種の台から そのまま落下して，衝撃をなるべく小さくすること を課題とした着地動作を，ランダムにそれぞれ 2 3 回行わせた。このとき，垂直跳と同様にして腕の 動作を制限したが，下肢や体幹の動作については何 も制限しなかった。

\section{3 実験方法}

本研究では, 身体を上体 (頭, 両腕, 体幹), 大 腿, 下腿, 足の 4 つの剛体にモデル化するため, 右 の耳珠点, 大転子, 大腿骨外側顆, 外果, 足先に反 射テープを利用したマーク(発泡スチロール製の球， 直径 $10 \mathrm{~mm}$ ）を両面テープで接着した。

Force platform（Kistler AG）上で上述の垂直跳 あるいは着地動作を行っている被験者をその右側方 から, Quick-MAG SYSTEM I (応用計測研究所 製)の計測用カメラにより露出時間 $1 / 1000$ 秒で撮影 した. そして, マークの位置を自動追跡し, その平 面座標を $60 \mathrm{~Hz}$ でパーソナルコンピュータに取り 込み，フロッピーディスクに記録した。

Force platform からの水平前後および鉛直方向 の地面反力, 力の作用点のデータは, サンプリング 周波数 $1 \mathrm{kHz}$ で A/D 変換した後，フロッピーディ スクに記録した. Quick-MAG SYSTEM I と力の データとの同期には，発光ダイオードを利用した同 期装置（電機計測販売製）を用いた。

\section{4 データ処理方法}

\section{4 .1 分析試技の選択}

垂直跳では，鉛直地面反力から力積および鉛直跳 躍初速度 $(v$, 離地時の身体重心の鉛直速度) を算出 し，それをもとに跳躍高 $\left(v^{2} / 2 g, g\right.$ は重力加速度) を全試技について求めた。そして, 各被験者につい て最大跳躍高が得られた試技（100\%）およびそれに 対する跳躍高の相対值が $80,60 ， 40 \%$ に近い試技 を分析試技として選択した。
着地動作では，鉛直地面反力を全試技について求 め, 各台高について最大鉛直地面反力が最も小さか つた試技を成功着地動作とし，被験者ごとに 5 試技 を分析試技として選択した。

\section{4 .2 データ処理}

選択された試技の座標デー夕をQuick-MAG SYSTEM I に付属の 2 次元 DLT 法を利用したプ ログラムで実長に換算した後, 3 次スプライン関数 により補間し， $100 \mathrm{~Hz}$ のサンプリング周波数相当 のデータに変換した。この変位データをデジタルフ イルターにより垂㨁跳では $6.2 \mathrm{~Hz}$ の, 着地動作で は $8.4 \mathrm{~Hz}$ の遮断周波数で平滑化した。 そして，2 次元リンクセグメントモデル（上体，大腿，下腿， 足の 4 リンクモデル) に力のデータとともに入力し て, 股, 膝, 足の各関節まわりのモーメント(以下, 関節モーメント）を求めた

変位データをデジタルフィルターにより平滑化す る場合の遮断周波数は，変位データの周波数分析の 結果をもとにして決定した。本研究で用いた遮断周 波数の程度であれば，身体重心の加速度の変化と地 面反力から求めたものとはよく一致することが確認 されている12).

関節モーメントに関節角速度を乗じて下肢関節の モーメントによるパワー(以下，パワー) を算出し, これらを動作区間（垂直跳ではしゃがみ込みによっ て地面反力が体重以下になった時点から離地まで, 着地動作では足接地から身体重心が最も低くなるま で）にわたって積分して関節モーメントによる力学 的仕事を求めた。 力学的仕事は, 符号に着目して, 正仕事，負仕事に分け，両者の絶対值の和を絶対仕 事とした。また各関節の仕事を総仕事で除して相対 的貢献度を求めた。ただし，本研究で算出した関節 モーメントは，関節まわりの主働筋群および拮抗筋 群のモーメントが合成されたものである。したがっ て，関節モーメントにもとづいて筋の発揮したパワ 一，仕事などを推定することには，限界があること に注意しておく必要がある。

なお, 身体部分の質量, 質量中心位置, 慣性モー メントの值は，阿江ら ${ }^{13)} の$ 方法によって求めた。 


\section{3. 結 果}

\section{1 垂直跳について}

\section{1 .1 努力度と跳躍高}

各被験者の最大跳躍高 $(0.363 \pm 0.034 \mathrm{~m})$ に対す る各試技の跳躍高の相対値と努力度との関係を全試 技（213試技）についてみると，努力度 $30 \%$ では相 対跳躍高が $37.6 \pm 14.8 \% ， 45 \%$ では $53.3 \pm 1.2 \%$, $60 \%$ では $62.9 \pm 10.6 \% ， 80 \%$ では $83.8 \pm 8.4 \%$ とな り，努力度 $80 \%$ までは相対跳躍高が努力度よりも 大きくなる傾向を示した。一方，努力度 $90 \%$ では， 逆に相効跳躍高（85.6土8.4\%）の方が小さかった。 また努力度が低い場合には，両者のずれは大きい が，高くなると，その差は小さくなった。

そこで, 本研究では, 努力度よりも相対跳躍高に 着目して，最大跳躍高の得られた試技（100\%）およ びその $80 ， 60 ， 40 \%$ に近い跳躍高の得られた試技 を選び，跳躍高の変化による下肢各部の貢献度を検
討することにした。このようにして選択した試技の 相対跳躍高は，80.2 $21.8 ， 61.3 \pm 2.0 ４ 3.6 \pm 3.6$ \%であった。

\section{1 .2 相対跳躍高の变化による下肢関節角度,}

関節モーメント, パワーの変化

図 1 は，相対跳躍高 $40 ， 60 ， 80 ， 100 \%$ の場合の 股，膝，足の各関節角度 (左), 関節モーメント (中)，パワー（右）を，典型的な変化を示した被験 者 $\mathrm{G}$ を例にして示したものである。いずれの図も， 上から股，膝，足を示し，時間軸は踏切時間（しゃ がみ込みによって地面反力が体重以下になった時点 から離地まで）を基準にして規格化されており，0 \%が踏切動作の開始を，100\%が離地時を示す。ま た正の関節モーメントは，いずれも関節の伸展モー

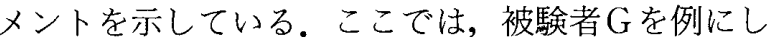
て, 相対跳躍高の変化に伴う各種力学量の変化を検 討することにする。

関節角度の変化（図 1 左）をみると，足関節では 相対跳躍高の変化に関係なく，ほほ一定の值を示し た。しかし，股および膝の関節角度は，相対跳躍高

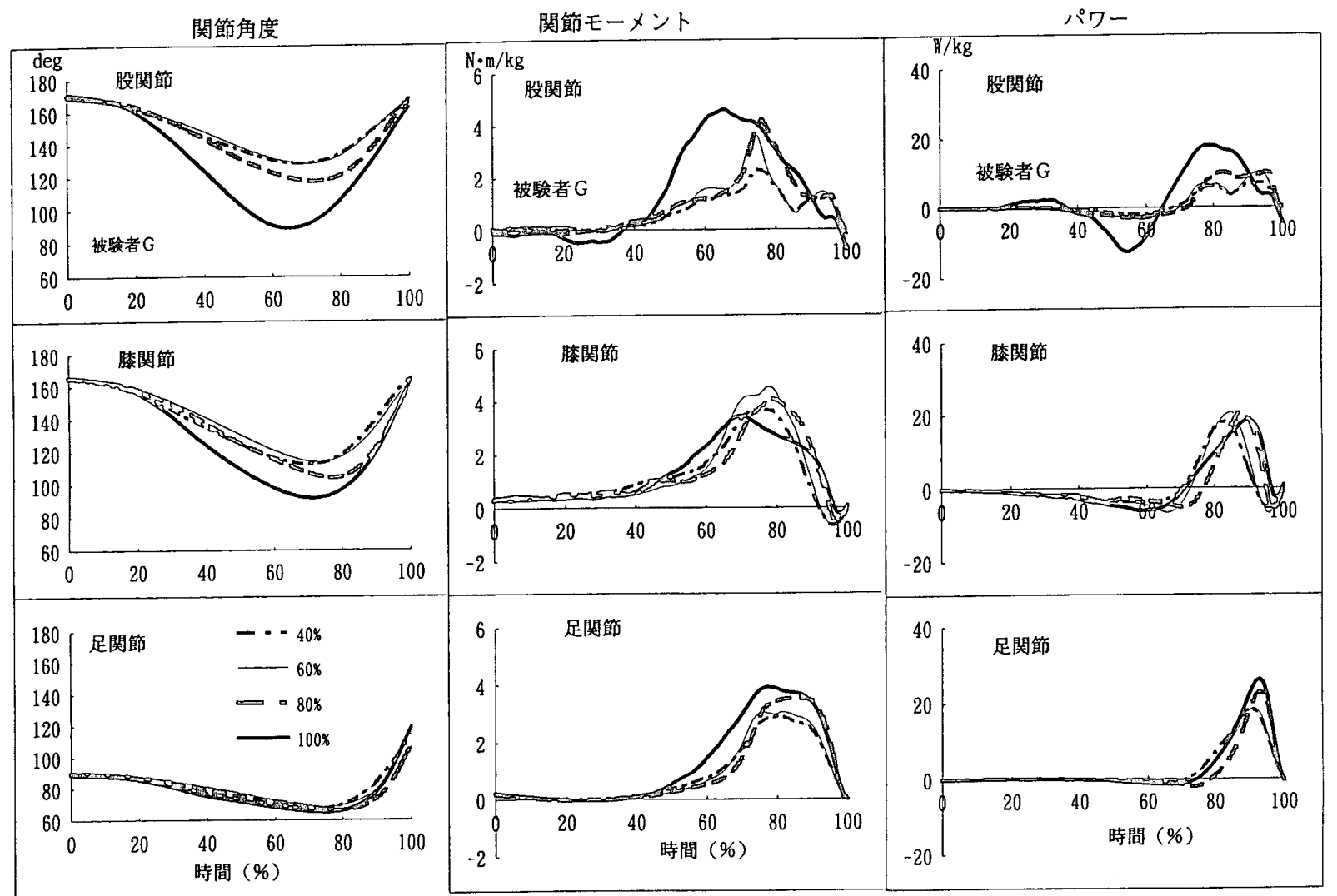

図 1 垂直跳の踏切に扔ける下肢関節の角度（左), 関節モーメント（中， パワー（右）の変化 
の大きさによって変化した。すなわち，40\%と 60 \%では，股㧍よび膝の関節角度にほとんど差はみら れなかったが，80\%から 100\%へ相対跳躍高が増大 すると，股抢よび膝関節の角変位が大きくなった。

跳躍動作の調整や制御に関する研究14)では，主と して膝関節角度の変化に注目している。しかし，こ れらの結果は，股関節角度の変化にも注目する必要 があることを示唆するものであろう。

関節モーメント（図 1中）をみると，足関節では 相対跳踓高が大きいほど，最大モーメントも大きく なる傾向を示した。しかし，膝関節ではそのような 傾向はみられず，むしろ跳躍高が最大下の場合に最 大モーメントが大きくなる傾向がみられた，股関節 では，最大跳躍高が得られた場合には，関節モーメ ントの変化パターン, 最大値とも他の場合と著しく 異なり，股関節が屈曲し上体が振り下げられる局面 からすでに大きな伸展モーメントが発揮されていた。

パワー（図 1 右）をみると，関節モーメントの場 合とほぼ同様の傾向がみられた，特に，最大跳躍高 の得られた場合の股関節のパワーは正，負ともに他 の場合よりも著しく大きかった。このことから，全 力の垂直跳では，大きな力学的仕事が股関節によっ てなされていることがわかる。

\section{1 .3 最大関節モーメントおよび最大パワー}

表 1 は，垂直跳の各試技に抢ける下肢関節のモ一 メントおよびパワーの最大值を示したものである.
関節モーメントをみると，足抢よび膝については 相対跳躍高が大きくなってもあまり大きな増大はな く，相対跳躍高 $100 \%$ では 60\%の場合よりも滕のモ 一メントが小さかった。一方，股関節については， 相対跳躍高とともに增大し，40\%抢よび $60 \%$ の場 合よりも $80 \%$ 以上の場合では有意に大きかった。 また，関節モーメントの大きさを比べると，相対跳 躍高が $60 \%$ までは滕一足一股の順であるが，80\% で足一股一膝，100\%では股一足一㯲となり，100\% では股関節のモーメントが最も大きくなった。

パワーについても関節モーメントと同様の変化を 示し，相対跳躍高が大きくなると，股関節のパワー が著増した。しかし，相対跳躍高の増大とともに差 は減少するが，いずれの跳躍高に扔いても足のパワ 一が最も大きく，ついで膝，股関節の順であった。

このようにいずれの跳躍高でも足のパワーが大き かったのは，ひとつには，足の慣性モーメントが小 さく，角速度が大きかったことによるものであろ う。また，図 1 に示したパワー曲線をみると，100 \%では膝のパワーが減少してくると(約 90\%時点)， 足のパワーが増大している。このことは，二関節筋 であるひふく筋を介して膝関節（大腿）のパワーが 足に伝達されていることを示唆していると考えられ る。例えば，Bobbert ら ${ }^{15}$ は，垂直跳の離地前 50 msでの足関節のパワーの $20 \%$ はひふく筋を介して 伝達されたパワーであると推定している。したがっ

表 1 垂直跳の踏切に㧍ける最大関節モーメントおよびパワー

\begin{tabular}{|c|c|c|c|c|c|c|}
\hline & & \multicolumn{4}{|c|}{ 相 対 跳 踓 高 } & \multirow{2}{*}{ 有意差 $(p<0.05)$} \\
\hline & & $40 \%$ & $60 \%$ & $80 \%$ & $100 \%$ & \\
\hline \multirow{7}{*}{$\begin{array}{l}\text { モーメント } \\
(\mathrm{N} \cdot \mathrm{m} / \mathrm{kg})\end{array}$} & $\mathrm{N}$ & 11 & 15 & 14 & 15 & \multirow{5}{*}{$\begin{array}{r}40,60<80,100 \\
80<100 \\
60>80\end{array}$} \\
\hline & 股関節 & 2.192 & 2.972 & 3.678 & 4.811 & \\
\hline & S.D. & 0.564 & 0.914 & 0.659 & 1.058 & \\
\hline & 㯟関節 & 3.885 & 3.943 & 3.522 & 4.149 & \\
\hline & S.D. & 0.718 & 0.573 & 0.512 & 0.604 & \\
\hline & 足関節 & 3.181 & 3.856 & 3.753 & 3.886 & \multirow[t]{2}{*}{$40<60,80,100$} \\
\hline & S.D. & 0.490 & 0.922 & 0.543 & 0.577 & \\
\hline \multirow{6}{*}{$\begin{array}{l}\text { パ } ワ \\
(\mathrm{~W} / \mathrm{kg})\end{array}$} & 股関節 & 7.445 & 9.860 & 13.857 & 17.623 & $40<60,80,100$ \\
\hline & S.D. & 2.117 & 2.802 & 2.190 & 2.853 & $60<80,100 \quad 80<100$ \\
\hline & 膝関節 & 19.277 & 19.417 & 19.669 & 20.008 & \multirow{4}{*}{$40<60,80,100$} \\
\hline & S.D. & 1.867 & 3.237 & 3.080 & 5.049 & \\
\hline & 足関節 & 18.332 & 23.464 & 24.847 & 23.634 & \\
\hline & S.D. & 4.354 & 6.255 & 5.127 & 5.836 & \\
\hline
\end{tabular}


て，このことを考慮すると，相対跳躍高 100\%に扮 ける足関節のパワーはもっと小さくなると考えられ る.

\subsection{4 下肢関節の力学的仕事と貢献度}

図 2 は各試技における下肢関節の力学的仕事の平 均値（身体質量当り）を，図 3 は総仕事に対する各 関節の相対的貢献度を示したもので，上から正仕 事，絶対仕事を示している。

力学的仕事をみると，正の総仕事は相刘跳躍高が 大きくなると，増大する傾向を示し，60\%と 80\%， $80 \%$ と $100 \%$ で有意に大きかった。しかし，足抒よ び膝の正仕事の增加は小さく，有意なものではなか つた。また，股関節の正仕事は $60 \%$ と $80 \%$ 押よび 80\%と 100\%で有意に増大した。このことは，負お よび絶対仕事についても同様であった。

下肢関節の相対的貢献度をみると，足関節の貢献 度は跳躍高にかかわらず，正仕事，絶対仕事ともほ ぼ一定か，わずかに減少する傾向を示した。また下 肢の総正仕事に対する膝関節の貢献度は有意な変化 を示さなかったが，絶対仕事は跳踓高の増大ととも に徐々に減少した。一方，股関節の貢献度は膝とは

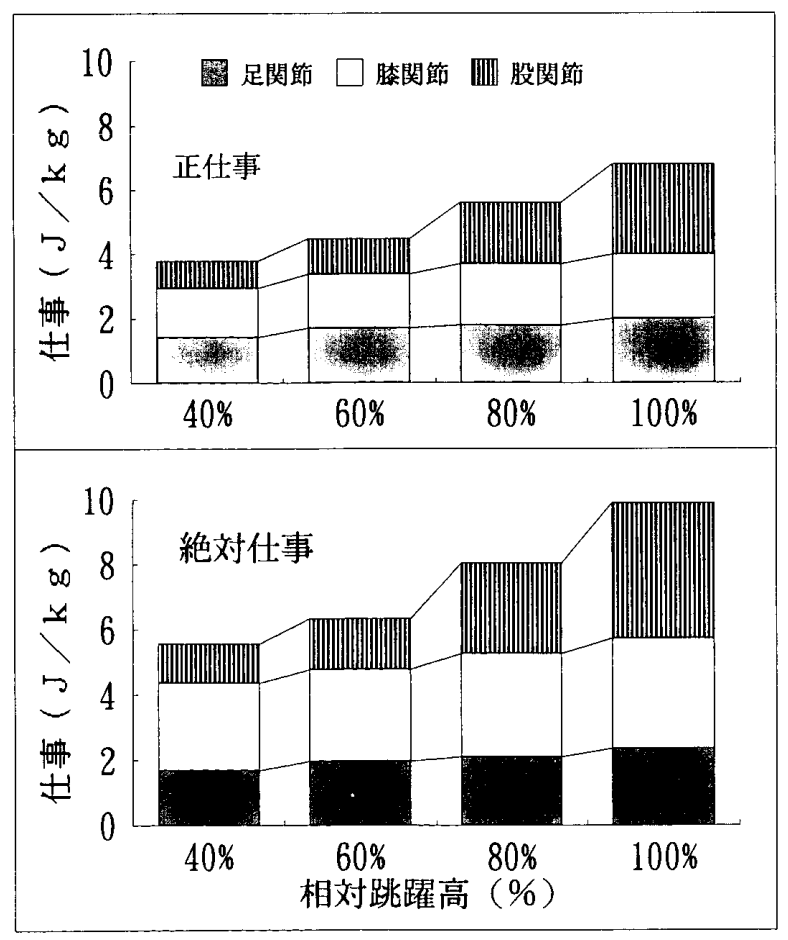

上：正仕事，下：絶対仕事

园 2 垂直跳の踏切に扔ける下肢関節の力学的仕事
逆に跳躍高の増大とともに増加し，60\%以上の場合 には有意な増加を示した。

また，関節の貢献度のタイプは，Hubley ら"が 述べているように，個人差がみられたが，表 2 に示 したように，相対跳躍高が大きくなると，股関節が 最も大きく，次いで膝，足の順になる，股一滕一足 のタイプのものが多くなった。

\section{2 着地動作について}

\section{2 .1 着地衝撃カについて}

表 3 は, 着地動作の各試技に抢ける最大鉛直力, 最小重心高，下肢関節のモーメントおよび負のパワ 一の最大值を示したものである。鉛直力は，0.25一

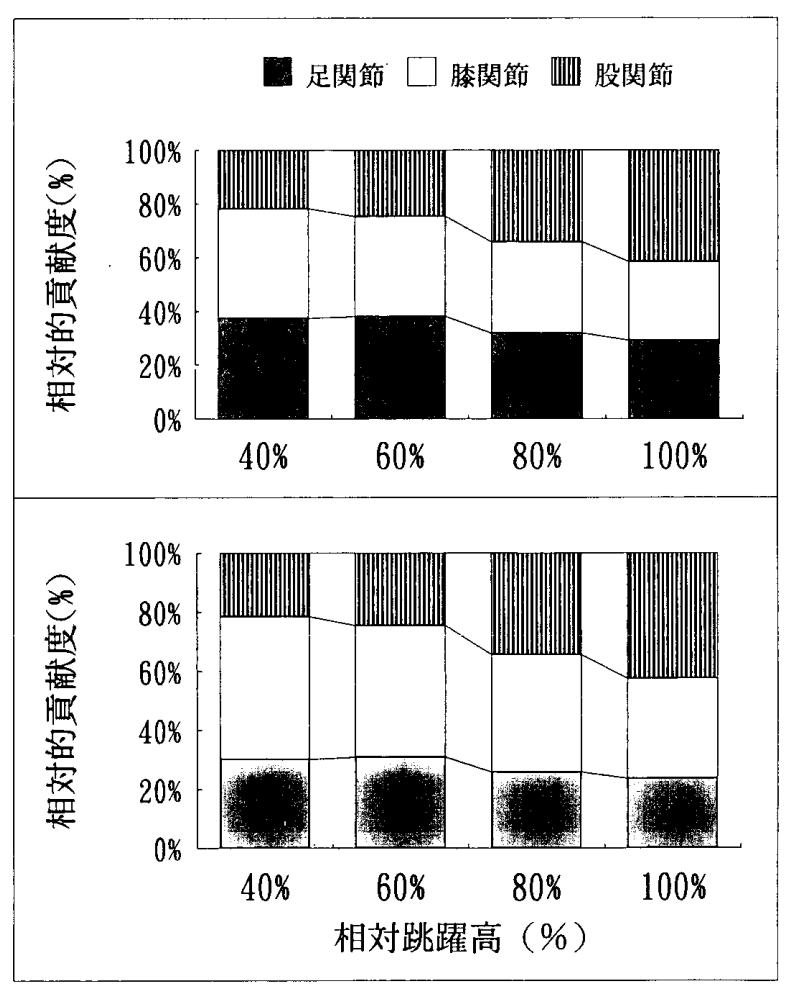

上：正仕事,下：絶対仕事

図 3 垂直跳の踏切における下肢関節の相対的貢献度

表 2 垂直跳における下肢関節の貢献度タイブ

\begin{tabular}{|c|c|c|c|c|}
\hline \multirow{2}{*}{ 貢献度タイプ } & \multicolumn{4}{|c|}{ 相 対 跳 躍 高 } \\
\hline & $40 \%$ & $60 \%$ & $80 \%$ & $100 \%$ \\
\hline 股一滕一足 & 0 & 0 & 3 & 9 \\
\hline 股－足一膝 & 0 & 0 & 0 & 2 \\
\hline 膝一股－足 & 3 & 4 & 7 & 3 \\
\hline 膝－足一股 & 8 & 8 & 3 & 1 \\
\hline 足一㯟－股 & 0 & 3 & 1 & 0 \\
\hline
\end{tabular}


表 3 着地動作における最大関節モーメントおよびパワー

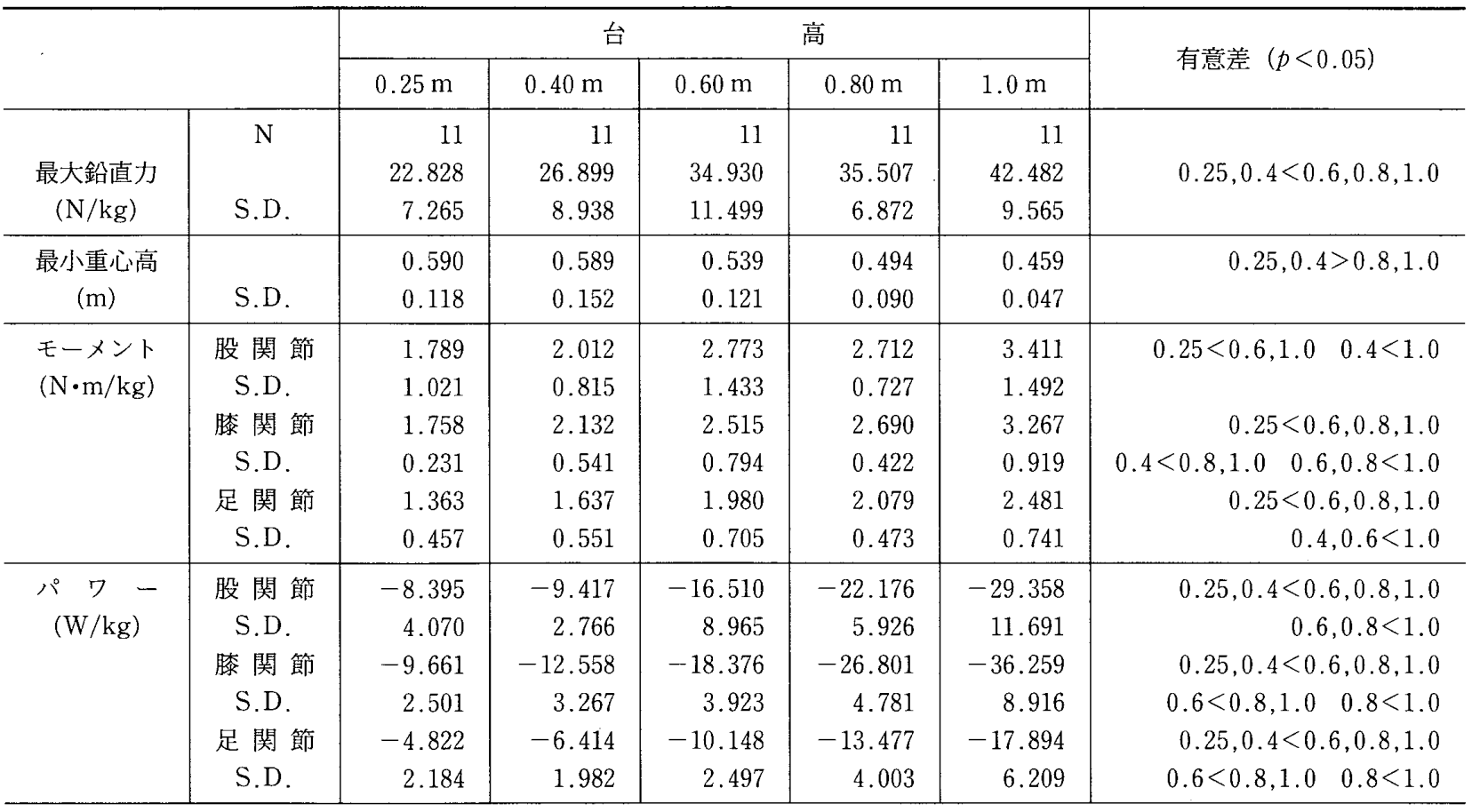

$0.4 \mathrm{~m}$ 間以外には有意差があり，台高が大きくなる と，衝撃力も増大した。これらの值は, Devita ら ${ }^{4)}$ が女子選手を対象に行った台高 $0.59 \mathrm{~m}$ からの着地 衝撃と比べると，かなり小さい．また，台高の増大 にともなって，落下のエネルギを受け止める距離の 指標である重心高も小さくなり，緩衝距離が大きく なる傾向を示した。

\section{2 .2 台高の変化による地面反カ, 下肢の関節 \\ 角度, 関節モーメント，パワーの変化}

図 4 は地面反力を，また図 5 は股，膝，足関節の 関節角度，関節モーメント，パワーを典型的な変化 を示した被験者Cを例にして示したものである。図 の示し方は図 1 と同様であるが，時間軸は接地時を ゼロとした実時間である。

地面反力の変化（図 4) をみると，台高が大きく なると，水平，鉛直の両成分ともピーク値が増大し ている．また，台高が $0.8 \mathrm{~m} ， 1.0 \mathrm{~m}$ になると，鉛 直成分のみでなく，水平成分も大きく，いずれもピ 一クが接地後 0.05 秒以内に出現している.

関節角度（図 5 左）は，接地前にいずれの関節も わずかに屈曲方向に変化し，着地動作の先取りが行 われていることがわかる。接地後約 0.15 秒まで足 の屈曲には，ばらつきがみられるが，その後は台高

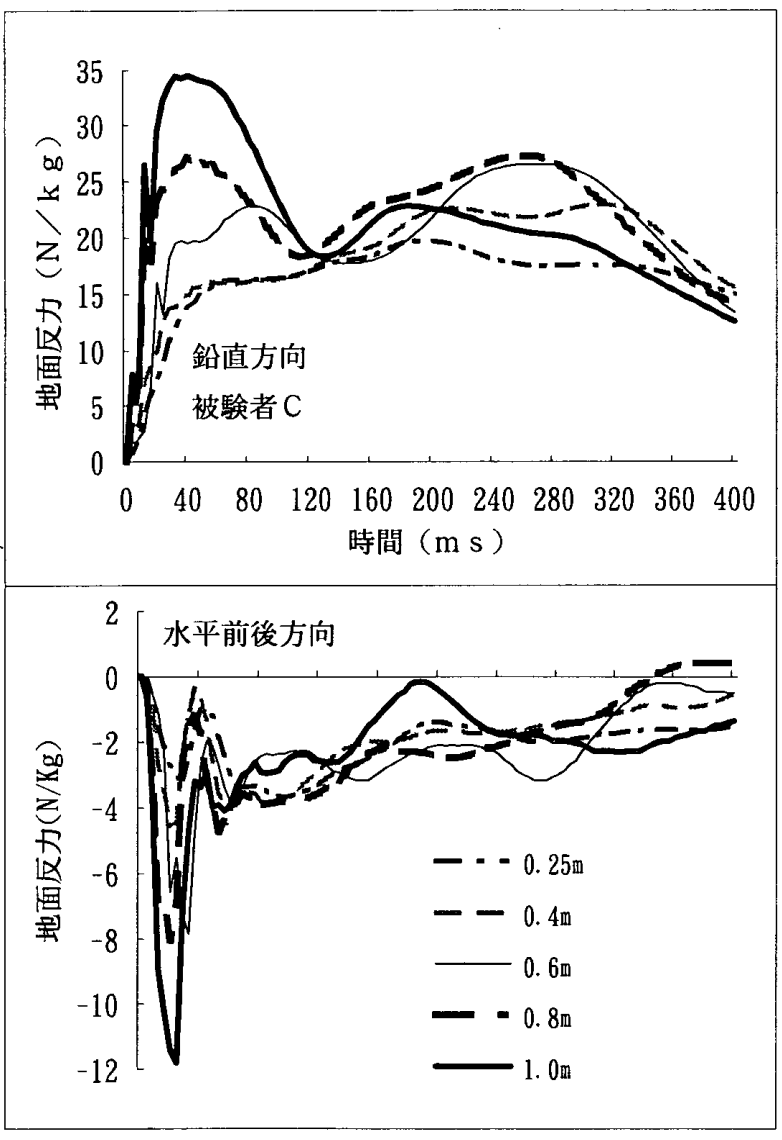

図 4 着地動作に㧈ける水平および鉛直地面反力 時間軸のゼロが接地時 


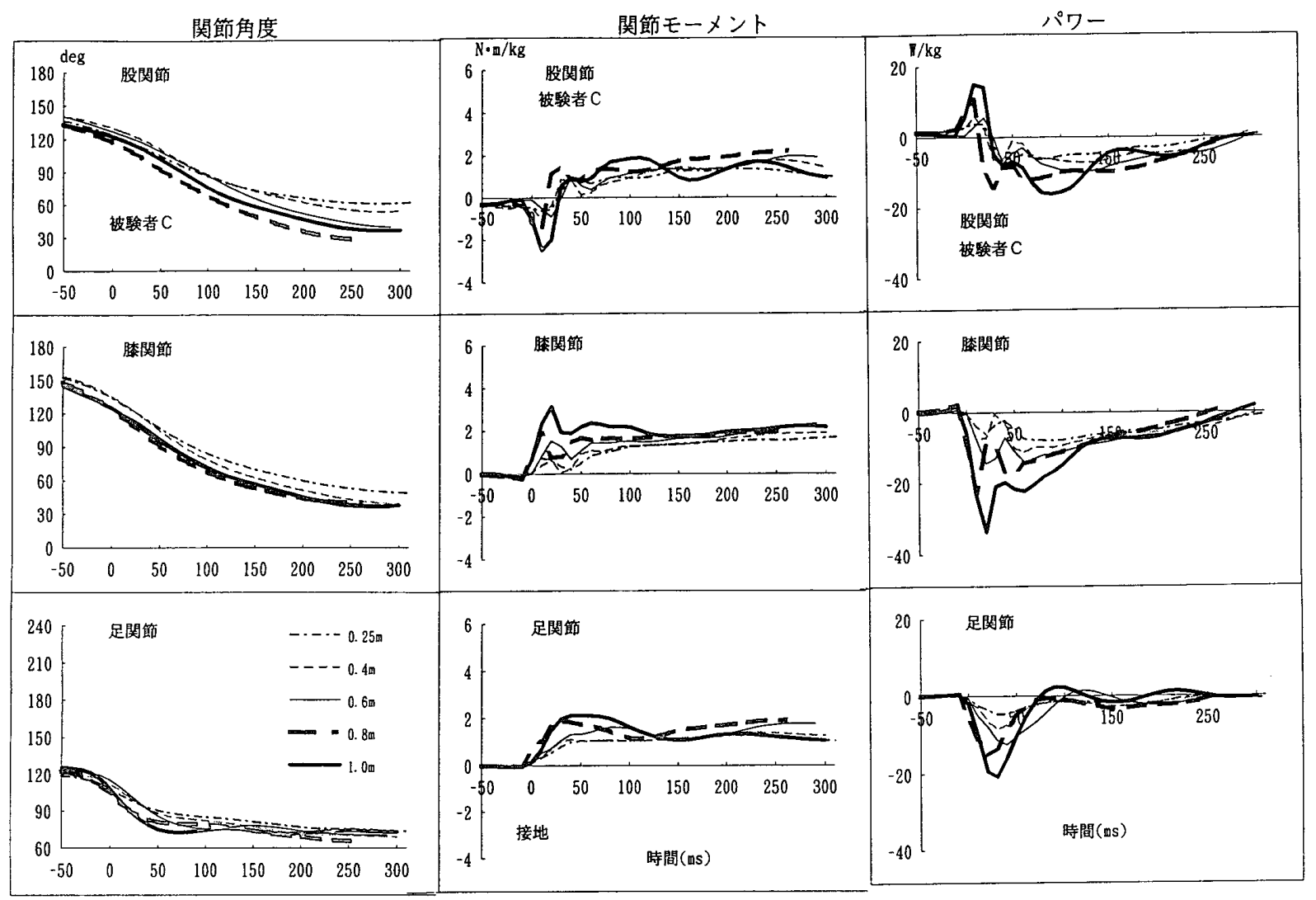

図 5 着地動作に㧍ける下肢関節の角度（左）, 関節モーメント（中，パワー（右）の変化 時間軸のゼロが接地時

にかかわらず関節角度 70 度前後の屈曲に留まって いた。一方，股抢よび膝関節の変化は，足関節と比 べてスムーズであるが，屈曲範囲は台高が大きいほ ど，大きくなる傾向にあった。

関節モーメント（図 5 中）をみると，いずれも接 地後 0.05 秒以内に大きなピークを生じている。こ れは，地面反力の変化とも一致し，これらの関節モ ーメントが大きな衝撃力により生じていることがわ かる。そして，身体の下向き速度を減少させるた め, 接地後, 足, 膝関節とも伸展モーメントを発揮 している。しかし股関節では，接地直前から接地後 0.03 秒あたりまでは屈曲モーメントが発揮されて おり，そのピークが膝の伸展モーメントのピークと ほぼ一致している。

この接地直前にみられた股関節の屈曲モーメント は，あらかじめ直立した体幹を前傾させて，接地の 準備をするのに役立っていると考えられる。また， 接地直後にみられた股関節の屈曲モーメントは, 大 きな膝伸展モーメント(膝関節の伸展モーメントは,
大腿を前方に回転させ，股関節を伸展させるモーメ ントとなる）に抗して体幹の前傾を保つ役割をはた していると考えられる。 パワー（図 5 右）は，接地直後の股関節のパワー を除けば，ほぼ着地動作の終了までいずれのパワー も負であり，足では足底屈筋群が，膝および股関節 では伸筋群がそれぞれ伸張性筋収縮により大きなパ ワーを発揮していることがわかる。また，足関節の パワーは，接地後約 0.15 秒でゼロ近くなるが，膝 と股関節ではその後も負のパワーを発揮している。

\section{2 .3 最大関節モータントおよび最大パワー}

表 3 に示したように，関節モーメントは，台高が 大きくなると，いずれの関節も大きくなる傾向を示 した。また，関節モーメントの大きさの順は，台高 $0.4 \mathrm{~m}$ を除いて股一滕一足となった。特に, 台高 $1.0 \mathrm{~m}$ では, 股関節と膝関節のモーメントの増大が 大きかったが，垂直跳の場合ほど股関節と㯟関節と の間に大きな差はなかった。

負のパワーは, 台高が大きくなると, いずれの関 
節も増大したままた，大きさは滕一股一足の順とな り，㯟のパワーが最も大きかった。このように，垂 直跳とは異なり，膝の負のパワーが大きかったこと は, 膝伸筋群が疾走の場合5) と同様に, 着地動作で も shock absorberの役割を担っていることを示し ていると考えられる。

\section{2 .4 下肢関節の力学的任事と貢献度}

図 6 は, 各台高における下肢関節の負の力学的仕 事を示したもので，下が負仕事を，上が下肢の総負 仕事に対する各関節の貢献度を示している. 負仕事 は, 台高が大きくなると, 増大する傾向を示し, 台 高 $0.25 \mathrm{~m}-0.4 \mathrm{~m}$ 間を除いて有意な差がみられ， 特に, 台高 $1.0 \mathrm{~m}$ での股関節の增大が著しかった。 相対的貢献度は，足おょび膝関節では大きな变化は みられなかったが, 台高が $1.0 \mathrm{~m} て ゙ は$ 股関節の貢 献度が $0.25 \mathrm{~m}-0.6 \mathrm{~m}$ の場合に比べて有意に大き かった．また，表 4 に示したように，垂直跳と同様

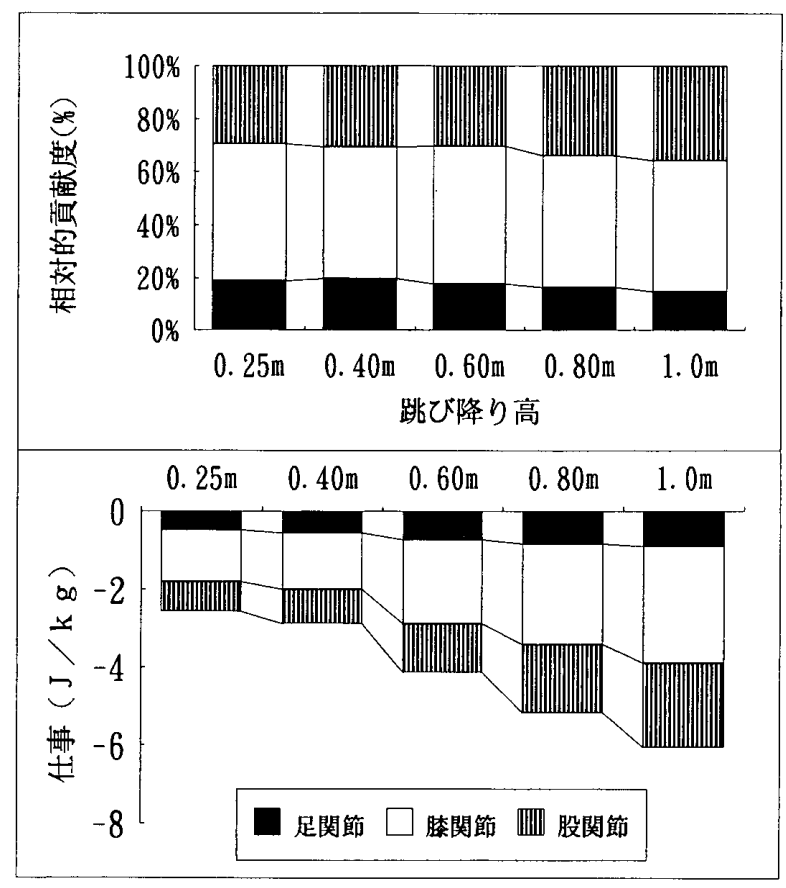

图 6 着地動作における下肢関節の力学的仕事扔よび 相対的貢献度

表 4 着地動作における下肢関節の貢献度タイプ

\begin{tabular}{c|c|c|c|c|c}
\hline \multirow{2}{*}{ 貢献度タイプ } & \multicolumn{5}{|c}{ 台 } \\
\cline { 2 - 6 } & $0.25 \mathrm{~m}$ & $0.40 \mathrm{~m}$ & $0.60 \mathrm{~m}$ & $0.80 \mathrm{~m}$ & $1.0 \mathrm{~m}$ \\
\hline 膝-股－足 & 8 & 7 & 10 & 9 & 9 \\
膝－足－股 & 3 & 4 & 1 & 1 & 0 \\
股一膝－足 & 0 & 0 & 0 & 1 & 2 \\
\hline
\end{tabular}

に，貢献度のタイプにも個人差がみられたが，多く の被験者が膝一股一足のタイプであった。

以上のことから，着地動作では，いずれの場合も まず足と膝関節が屈曲して大きな衝撃力に抗しなが ら, 次いで体幹が前傾して大きな股関節伸展モーメ ントが発揮できる股関節角度 (100 から 120 度 $)^{16)}$ なった後, 股関節が参加して身体の下向き速度を減 少させると考えられる。そして台高が大きくなる と，膝や股関節が大きな関節モーメントやパワーを 発揮するようになると考えられる。

\section{4. 考察}

\section{1 負荷の大きさと下肢関節の力学的仕事 および貢献度}

垂直跳では跳躍高を，着地動作では台高を身体に 加わる負荷と考えることができる．そこで，これら の負荷の増大に伴って, 下肢関節のパワー, 力学的 仕事，貢献度などがどのように変化するかを検討す る.

相対跳躍高や台高の増大にともなって，膝や股関 節の角変位, モーメントおよびパワーが徐々に増大 した。そして，すでに述べたように，垂直跳では跳 躍高の, 着地動作では台高の増大にともなって, 滕 関節の,さらに負荷が大きい場合には股関節のモー メントおよびパワーの増大が著しかった。また，下 肢関節の力学的仕事も足や滕では顕著な増大を示さ なかったが，股関節の力学的仕事や貢献度は垂直跳 では跳躍高 $60 \%$ 以上で，着地動作では台高 $0.8 \mathrm{~m}$ 以上で有意な増大を示した。

これらのことは，言い換えると，負荷が小さく， あまり大きなパワーを発揮する必要がない場合に は，足および膝関節まわりの筋群が使われ，さらに 大きな負荷が加わるようになると，足や膝の筋群の 活動も増えるが，それ以上に股関節まわりの伸筋群 の関与が大きくなることを意味するものであろう.

これと同様のことは，他の運動でも報告されてい る. 阿江ら ${ }^{5)}$ は, 走速度を約 $3 \mathrm{~m} / \mathrm{s}$ から全速（約 10 $\mathrm{m} / \mathrm{s}$ ）まで変化させたときの足，滕，股の関節の力 
学的仕事の変化を測定した. そして足関節の力学的 仕事は走速度が増大しても顕著に増大しないが，膝 の屈筋群の負仕事㧍よび股の伸筋群および屈筋群の 正仕事の増大が著しいことを報告している。また Fukashiro $^{3)}$ は, 垂植跳, ホッピング, スタートダ ッシュ, 全速疾走の脚伸展局面に押ける下肢関節の モーメントや力学的パワーを測定した結果, 最大努 力での脚伸展においては, 最大下ょりも股関節の貢 献度が増加すると述べている。 Devita ら ${ }^{4)}$ は, 台高 $0.59 \mathrm{~m}$ からの着地動作で stiff landing では力学的 仕事への足, 膝, 股関節の貢献度はそれぞれ 50, 30，20\%であるが， soft landing ではそれぞれ 37, $37,25 \%$ となり，膝や股関節の相対的貢献度が soft landing では大きくなることを報告している.

これらのことから, 最大努力あるいは全力を発揮 する運動や大きな負荷の加わる運動では，股関節の 力学的仕事抢よび貢献度が大きくなると考えられ る.

\section{2 下肢筋群の力学的仕事能と関節の動員}

そこで，垂直跳の踏切や着地動作に関与する下肢 筋群が，どれくらいの力学的仕事をすることができ るのか（ここでは，仮に，力学的仕事能 Mechanical Work Capacity と呼ぶ）を文献をもとに検討す る。

Hoy $ら^{16)}$ は，18 個の下肢筋の解剖学的デー夕を もとにして，下肢の筋骨格モデルを構築している。 そして，股，膝，足の各関節まわりの筋・腱が等尺 性筋収縮によって発揮できる総合的なモーメントを 理論的に求め，それらを関節角度と関係づけて示 し，モーメントが関節角度によって大きく変化する と述べている。Hoy らの示したモーメント一関節 角度曲線を, 股関節㧍よび膝関節では 120 度, 足関 節では 50 度（足背屈 25 度から足底屈 25 度）の籁囲 にわたって積分し，これらの筋群の力学的仕事能を 求めると，股関節では抢よそ $375 \mathrm{~J}$, 膝関節では $398 \mathrm{~J}$ ，足関節では $154 \mathrm{~J}$ となった。また，曲線から 最大モーメントを読み取ると，股関節は抢よそ 250 $\mathrm{N} \cdot \mathrm{m}$ ，滕関節は $300 \mathrm{~N} \cdot \mathrm{m}$ ，足関節は $215 \mathrm{~N} \cdot \mathrm{m}$ とな る。また，抵抗の指標として部分の質量中心を通る
表 5 下肢各部および関節の慣性モーメント， 力学的仕事能, 負担度

(身体質量 $64.3 \mathrm{~kg}$ の場合)

\begin{tabular}{c|c|c|c|c}
\hline 関節 & 部 分 & $\begin{array}{c}\text { 慣性モーメント } \\
\text { 左右軸 }\left(\mathrm{kg} \cdot \mathrm{cm}^{2}\right)\end{array}$ & $\begin{array}{c}\text { 力学的仕 } \\
\text { 事能 }(\mathrm{J})\end{array}$ & $\begin{array}{c}\text { 負担度 } \\
\left(\mathrm{kg} \cdot \mathrm{cm}^{2} / \mathrm{J}\right)\end{array}$ \\
\hline 股関節 & 胴体十大腿 & 5697.5 & 375.2 & 15.18 \\
滕関節 & 大腿十下腿 & 1138 & 398.62 & 2.85 \\
足関節 & 下腿十足 & 310.8 & 154.15 & 2.02 \\
\hline
\end{tabular}

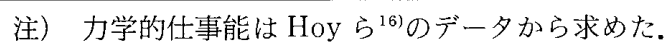
負担度 $=$ 慣性モーメント／力学的仕事能

左右軸まわりの慣性モーメントを, 本研究の被験者 を例にして求め，両足を 1 として表すと，胴体が約 270 倍, 大腿が約 50 倍, 下腿が約 17 倍になる.

表 5 は，このようにして求めた慣性モーメント， 力学的仕事能などを平均的な被験者についてまとめ たものである。表 5 に示した慣性モーメントは，股 関節では胴体および大腿が，膝関節では大腿衫よび 下腿が，足関節では下腿捛よび足がそれぞれ負荷に なると考え，各体節の慣性モーメントを加えたもの である。また負担度は，慣性モーメントを関節の力 学的仕事能で除したもので, 筋群の力学的仕事能に 対する負担の大きさの指標である。この表から，股 関節まわりの筋群は大きな力学的仕事能をもつが, 負担度が足や膝関節の $5-7$ 倍もあり, 運動に動員 された場合には，股関節やそのまわりの筋群にはか なり大きな負担がかかると推測される。一方，足や 膝関節では，関係する質量や慣性モーメントが小さ いので，負担は小さくなると考えられる。これらの 負担度や力学的仕事能と本研究で得られた結果を関 係づけると，次のようになるであろう。

すなわち，軽く跳ぶだけでよい場合や低い台高か らの着地動作では, 足の足底屈筋群や膝の伸筋群が 動員されたように，消費エネルギや負担を小さくす るため, 質量や慣性モーメントの小さい部分が使わ れる。そして，徐々に高く跳ぶ，あるいは台高が大 きくなると, 筋力やパワー発揮能力が高い膝の筋群 のパワーが増大してくる。さらに最大(全力)か，そ れに近い場合には，膝関節の角変位も大きくなる が，さらに質量の大きい胴体を動員して，全身の質 量中心の変位を大きくすると考えられる.しかし， 股関節伸筋群の筋力やパワー発揮能力は大きいが, 
慣性の大きな胴体を動かすことになるので，相対的 には負担が大きくなると考えられる。したがって， 身体の質量中心の変位を大きくする必要がない場合 には，胴体をあまり大きく動かさないと推測され る.

われわれの運動に抢ける身体各部の使い方を決め る原則や基準，あるいは最適化する場合の目的関数 には，すでに述べたように様々なものが提案されて いる，宇野6) は腕の運動について筋トルク変化最小 という基準を，山崎ら〉は自由歩行について総代謝 エネルギにもとづく移動仕事率を，Vaughan ${ }^{17)}$ は 日常動作やスポーツ運動について筋トルクの総和最 小あるいは筋への負荷最小を，またWood ら ${ }^{8}$ は短 距離走について筋群の力学的仕事最小を, Hatze ${ }^{18)}$ は筋トルクの時間積分值の自乗などを基準として用 いている。また，Pandy ら ${ }^{9)}$, 藤井ら ${ }^{10}$ は垂直跳に おける最適動作を最大跳躍高あるいは動作時間など の拘束条件のもとで，また Borysiewicz ら ${ }^{11}$ はバ ーベルの軌跡を拘束条件として重量挙げの最適動作 を見出そうとしている。

本研究で得られた下肢各部の垂直跳の踏切動作お よび着地動作への貢献の仕方とこれらの基準や条件 を関連づけて考えると，次のようになろう。すなわ ち，要求されるパワーあるいは負荷が小さい場合に は，力学的仕事（消費エネルギ）あるいは負担をな るべく小さくするような基準が，80\%までの中程度 の負荷では筋モーメントの総和あるいは筋の応力な ぞの筋力に関する基準が優先される. しかし, 最大 の力やパワー, あるいはパフォーマンスが要求され るようになってくると，たとえエネルギや負担が大 きくなっても, 運動課題の達成が最優先され, 結果 やパフォーマンスが最大になるように身体各部が動 員されると推測される。運動において要求されるパ ワーや負荷の大きさ，運動課題によって基準や原則 が変化するという仮説は, 今後, 各種の運動につい て検討する必要があろうが，よい動きを考察する場 合の観点のひとつになり得ると考えられる。

本研究の一部は, 第 10 回日本バイオメカニクス学会大会 （1990）において発表した。
本研究は, 平成元年度筑波大学学内プロジェクト研究費の 助成を得て行われたものである。

リアルタイム動作解析システム (Quick-MAG SYSTEM I) の使用に際しては，電機計測販売株式会社から援助をいただ いた。ここに記して感謝致します。

\section{参考文献}

1) Hubley, C.L. \& Wells, P.W. : A work-energy approach to determine individual joint contributions to vertical jump performance, Eur. J. Appl. Physiol., 50, 247-254, (1983).

2) Bobbert, M.F., Mackay, M., Schinkelshoek, D., Huijing, P.A. \& van Ingen Schenau, G.J. : Biomechanical analysis of drop and countermovement jumps, Eur. J. Appl. Physiol., 54, 566-573, (1986).

3) Fukashiro, S. : Moment of force and mechanical power in joints during leg extension, Biomechanics XI-B (eds. de Groot, et al.), 938-942, (1988).

4) Devita, P. \& Skelly, W.A. : Effect of landing stiffness on joint kinetics and energetics in the lower extremity, Med. Sci. Sports Exerc., 24(1), 108-115, (1992).

5）阿江通良, 宮下憲, 大木昭一郎, 啮川㑆二：機械的パワー からみた疾走における下肢筋群の機能および貢献度, 筑 波大学体育科学系紀要, 9, 229-239, (1986).

6）宇野洋二：腕の熟練運動の神経回路モデル，バイオメカ ニズム学会誌, 14(1)，10-16，(1990).

7）山崎信寿, 長谷和徳：自由歩行における歩調・歩幅の生体 力学的决定基準，バイオメカニズム 11，179-190, 東京大 学出版会, (1992).

8) Wood, G.A., Marshall, R. N. \& Jennings, L.S. : Optimal requirements and injury propensity of lower limb mechanics in sprint running, Biomechanics X-B, 869 873, Human Kinetics Publishers, (1987).

9) Pandy, M.G. \& Zajac, F.E. : Optimal muscular coordination strategies for jumping, $J$. Biomech., 24(1), 1-10, (1991).

10）藤井範久，森脇俊道：垂直跳び動作と筋力特性に関する 研究, バイオメカニズム 11，167-178, 東京大学出版会, (1992) .

11) Borysiewicz, M., Bucka, J., \& Komor, A. : Optimization of sports techniques using the example of weight lifting, Biomechanics VII-B, 305-312, Human Kinetics Publishers, (1981)

12）阿江通良：高くとぶための跳に関する運動生力学的研究 一踏切における身体各部の貢献とメカ二ズムについて 一, 昭和 56 年度筑波大学大学院教育学博士諭文, (1982).

13）阿江通良, 湯海鵬, 横井孝志：日本人アスリートの身体部 分慣性特性の推定, バイオメカニズム $11,23-33$, 東京大 学出版会, (1992).

14）定本朋子, 大築立志：跳躍動作に打ける出力制御の正確 性一跳躍距離の grading および再現の特性一，体育学研 究, $22: 215-219$, (1977)

15) Bobbert, M.F., Huijing, P.A. \& van Ingen Schenau, G.J. : An estimation of power output and work done by the human triceps surae muscle-tendon complex in jumping, J. Biomech., 19(11), 899-906, (1986).

16) Hoy, M.G., Zajac, F.E. \& Gordon, M.E. : A mus- 
culoskeletal model of the human lower extremity: The effect of muscle, tendon, and moment arm on the moment-angle relationship of musculotendon actuators at the hip, knee, and ankle, J. Biomech. 23(2), 157-169, (1990).

17) Vaughan, C.L., Hay, J.G. \& Andrews, J.G. : Closed loop problems in biomechanics Part II-An optimiza. tion approach-, J. Biomechanics, $15: 201-210$, (1982).

18) Hatze, H.: Optimization of human motions, Biome chanics III, 138-142, Human Kinetics Publishers, (1973). 


\title{
CONTRIBUTIONS OF LOWER LIMB JOINTS AND LEVEL OF POWER OUTPUT IN VERTICAL JUMP AND LANDING
}

\author{
Michiyoshi AE, Shoichiro OHKI and Junji TAKAMATSU
}

\author{
Institute of Health and Sport Sciences, University of Tsukuba
}

The purposes of this study were to identify the changes in moments, powers, mechanical works, and contributions of the lower limb joints in vertical jump takeoff and landing from vertical fall, and to propose an interpretation of recruitment of the body segments in sports skills.

Fifteen male track and field athletes as subjects performed vertical jumps with no arm swing in six different levels of effort : 100\% (maximum effort), 90,80,60,45, and 30\%. Eleven subjects landed from the five different heights of $0.25,0.4$, $0.6,0.8$, and $1.0 \mathrm{~m}$ so as to minimize the landing impact force as much as possible. Five reflective landmarkers on the lower extremity were automatically detected at $60 \mathrm{~Hz}$ with Quick-Mag System I, and interpolated using cubic spline function to convert data equivalent to sampling rate of $100 \mathrm{~Hz}$. Ground reaction force data were sampled at $1000 \mathrm{~Hz}$ with a Kistler force platform. Two-dimensional inverse dynamics were performed on a four-link segment model to obtain the moments and powers of the hip, knee, and ankle. Mechanical works and contributions of the lower limb joints were calculated from these data.

The results were summarized as follows.

1. With changes in relative jumping height the maximum joint moment and power on the hip increased remarkably, while those of the knee and ankle did not show such a sharp increase. Relative contributions of the ankle, knee, and hip to the total positive mechanical work changed from $37.6,40.4$, and $22.0 \%$ for $40 \%$ jumping height to $29.4,29.0$, and $41.6 \%$ for maximum jump, respectively.

2. With increases in heights of fall, the maximum joint moments and negative powers increased in all three joints. The hip showed the maximum muscle moments, followed by the knee and ankle. The knee joint exerted the greatest negative power at every height to dissipate the energy of the fall. Relative contributions of the ankle, knee, and hip were 19.6, 51.8, and 28.6\% for height of $0.25 \mathrm{~m}$ and $14.8,48.8$, and $36.4 \%$ for height of $1.0 \mathrm{~m}$.

Considering these results together with the inertia properties and mechanical work capacities of the lower limb muscles, it would be speculated that the smaller segments must first be recruited so that energy and load on the body can be minimized, but in the case of the maximum power output, the greater segments with large inertia and mechanical work capacities may join the preceding segments, where achieving the objectives of the skills may take priority over the principles of minimizing energy and muscle stress. 